Cellular Physiology
and Biochemistry and Biochemistry Published online: July 11, 2016

Accepted: June 13, 2016

This article is licensed under the Creative Commons Attribution-NonCommercial-NoDerivatives 4.0 International License (CC BY-NC-ND) (http://www.karger.com/Services/OpenAccessLicense). Usage and distribution for commercial purposes as well as any distribution of modified material requires written permission.

\title{
Micafungin-Induced Suicidal Erythrocyte Death
}

\author{
Thomas Peter $^{\mathrm{a}}$ Rosi Bissinger ${ }^{\mathrm{a}}$ Elena Signoretto ${ }^{\mathrm{a}, \mathrm{b}} \quad$ Andreas F. Mack ${ }^{\mathrm{c}}$ Florian Lang ${ }^{\mathrm{a}}$
}

aDepartments of Cardiology, Cardiovascular Medicine and Physiology, Eberhard-Karls-University of Tuebingen, Tuebingen, Germany; ${ }^{b}$ Department of Pharmacological and Biomolecular Sciences, Università degli Studi di Milano, Milano, Italy; Institute of Anatomy, University of Tuebingen, Tuebingen, Germany

\section{Key Words}

Phosphatidylserine $・$ Cell volume $•$ Eryptosis $•$ SB203580 • zVAD • Calcium $•$ Hemolysis

\begin{abstract}
Background/Aims: The antifungal drug Micafungin is used for the treatment of diverse fungal infections including candidiasis and aspergillosis. Side effects of Micafungin treatment include microangiopathic hemolytic anemia and thrombocytopenia with microvascular thrombosis. The development of thrombosis may be fostered by stimulation of eryptosis, the suicidal death of erythrocytes characterized by cell shrinkage and cell membrane scrambling with phosphatidylserine translocation to the erythrocyte surface. Triggers of eryptosis include increase of cytosolic $\mathrm{Ca}^{2+}$ activity $\left(\left[\mathrm{Ca}^{2+}\right]\right)$, oxidative stress, ceramide, activated protein kinase C (PKC), casein kinase $1 \alpha$ or p38 kinase and activated caspases. The present study explored, whether Micafungin induces eryptosis. Methods: Flow cytometry was employed to estimate phosphatidylserine abundance at the erythrocyte surface from annexin-V-binding, cell volume from forward scatter, $\left[\mathrm{Ca}^{2+}\right]_{i}$ from Fluo3-fluorescence, abundance of reactive oxygen species (ROS) from DCFDA dependent fluorescence, and ceramide abundance at the erythrocyte surface utilizing specific antibodies. Hemolysis was quantified by measuring haemoglobin concentration in the supernatant. Results: A 48 hours exposure of human erythrocytes to Micafungin $(10-25 \mu \mathrm{g} / \mathrm{ml})$ significantly increased hemolysis and the percentage of annexin$\mathrm{V}$-binding cells, and significantly decreased forward scatter. Micafungin $(25 \mu \mathrm{g} / \mathrm{ml})$ did not significantly modify Fluo3-fluorescence, DCFDA fluorescence, or ceramide abundance. The effect of Micafungin on annexin-V-binding was not significantly modified by removal of extracellular $\mathrm{Ca}^{2+}$, by PKC inhibitor staurosporine $(1 \mu \mathrm{M})$, p38 kinase inhibitor SB203580 $(2 \mu \mathrm{M})$, casein kinase $1 \alpha$ inhibitor D4476 $(10 \mu \mathrm{M})$ or pancaspase inhibitor ZVAD $(10 \mu \mathrm{M})$. Conclusions: Micafungin triggers hemolysis and eryptosis with cell shrinkage and phospholipid scrambling of the erythrocyte cell membrane.
\end{abstract}




\section{Introduction}

Micafungin has been employed for the treatment and prophylaxis of diverse fungal infections [1-10] including candidiasis [5-37] and aspergillosis [5-8, 12, 15, 24, 27-30, 32, 33, 36, 38, 39]. Side effects of Micafungin treatment include thrombotic thrombocytopenic purpura (TTP), a condition characterized by microangiopathic hemolytic anemia and thrombocytopenia with microvascular thrombosis [40].

Stimulators of thrombosis include triggering of eryptosis, the suicidal death of erythrocytes characterized by cell shrinkage [41] and cell membrane scrambling with phosphatidylserine translocation to the cell surface [42]. Phosphatidylserine exposing erythrocytes further adhere to the vascular wall [43], stimulate blood clotting and thus foster thrombosis [44-46]. Accordingly, stimulation of eryptosis may lead to impairment of microcirculation [44, 47-51].

Signaling mechanisms stimulating eryptosis include $\mathrm{Ca}^{2+}$ entry with increase of cytosolic $\mathrm{Ca}^{2+}$ activity $\left(\left[\mathrm{Ca}^{2+}\right]_{\mathrm{i}}\right)[42]$, ceramide [47], caspases $[42,52,53]$, as well as several kinases including casein kinase $1 \alpha$, Janus-activated kinase JAK3, protein kinase $\mathrm{C}$, and p38 kinase [42]. Eryptosis is inhibited by AMP activated kinase AMPK, cGMP-dependent protein kinase, and PAK2 kinase and sorafenib/sunitinib sensitive kinases [42].

Eryptosis is triggered by oxidative stress [42], energy depletion [42] and a wide variety of xenobiotics [42, 54-84].

The present study explored whether Micafungin could stimulate eryptosis. To this end, human erythrocytes were exposed to Micafungin and phosphatidylserine surface abundance, cell volume, $\left[\mathrm{Ca}^{2+}\right]_{i}$, abundance of reactive oxygen species (ROS) and ceramide determined by flow cytometry.

\section{Materials and Methods}

Erythrocytes, solutions and chemicals

Fresh Li-Heparin-anticoagulated blood samples were kindly provided by the blood bank of the University of Tübingen. The study is approved by the ethics committee of the University of Tübingen (184/2003 V). The blood was centrifuged at $120 \mathrm{xg}$ for $20 \mathrm{~min}$ at $20^{\circ} \mathrm{C}$ and the platelets and leukocytes-containing supernatant was disposed. Erythrocytes were incubated in vitro at a hematocrit of $0.4 \%$ in Ringer solution containing (in mM) $125 \mathrm{NaCl}, 5 \mathrm{KCl}, 1 \mathrm{MgSO}_{4}, 32 \mathrm{~N}$-2-hydroxyethylpiperazine-N-2-ethanesulfonic acid (HEPES; pH 7.4), 5 glucose, $1 \mathrm{CaCl}_{2}$, at $37^{\circ} \mathrm{C}$ for 48 hours. Where indicated, erythrocytes were exposed for 48 hours to Micafungin (Selleckchem, Munich, Germany). To test for an involvement of oxidative stress, erythrocytes were exposed for 48 hours to a combination of Micafungin and antioxidant N-acetylcysteine (Sigma Aldrich, Hamburg, Germany). Involvement of protein kinase C or p38 kinase was analyzed by exposure of erythrocytes for 48 hours to a combination of Micafungin and either PKC inhibitor staurosporine (Tocris bioscience, Bristol, UK) or p38 kinase inhibitor SB 203580 (Tocris bioscience). A putative role of casein kinase $1 \alpha$ was elucidated by exposure of erythrocytes for 48 hours to a combination of Micafungin and casein kinase $1 \alpha$ inhibitor D4476 (Sigma Aldrich, Hamburg, Germany). Involvement of caspases was tested by exposure of erythrocytes for 48 hours to a combination of Micafungin and pancaspase inhibitor zVAD (Enzo Life Sciences, Lörrach, Germany).

Annexin-V-binding and forward scatter

After incubation under the respective experimental condition, a $150 \mu \mathrm{l}$ cell suspension of erythrocytes was centrifuged at $630 \mathrm{xg}$ for $3 \mathrm{~min}$ and, after trashing the supernatant, the erythrocytes were stained with Annexin-V-FITC (1:200 dilution; ImmunoTools, Friesoythe, Germany) in Ringer solution containing $5 \mathrm{mM} \mathrm{CaCl}{ }_{2}$ at $37^{\circ} \mathrm{C}$ for $20 \mathrm{~min}$ under protection from light. The annexin-V-abundance at the erythrocyte surface was subsequently determined on a FACS Calibur (BD, Heidelberg, Germany). Annexin-V-binding was measured with an excitation wavelength of $488 \mathrm{~nm}$ and an emission wavelength of $530 \mathrm{~nm}$. A marker (M1) was placed to set an arbitrary threshold between annexin-V-binding cells and control cells. The same threshold was used for untreated and Micafungin treated erythrocytes. A dot plot of forward scatter (FSC) vs side scatter (SSC) was set to linear scale for both parameters. The threshold of forward scatter was set at the default value of " 52 ". 


\section{Cellular Physiology Cell Physiol Biochem 2016;39:584-595

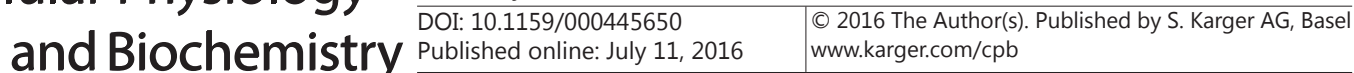

Peter et al.: Micafungin-Induced Eryptosis

\section{Confocal microscopy}

In order to visualize the effect of Micafungin on F-actin in human erythrocytes, Phalloidin eFluor ${ }^{\circ} 660$ (eBioscience, San Diego, USA) was used. Briefly, treated erythrocytes were stained with Phalloidin eFluor ${ }^{\circ}$ 660 at a dilution of $1: 100$ for $45 \mathrm{mins}$ in the dark at $37^{\circ} \mathrm{C}$. In order to visualize phosphatidylserine exposure, erythrocytes were additionally stained with Annexin-V-FITC (1:200 dilution; ImmunoTools, Friesoythe, Germany) for 30 mins in the dark at $37^{\circ} \mathrm{C}$. The erythrocytes were washed twice and were finally resuspended in $200 \mu$ l Ringer solution containing $5 \mathrm{mM} \mathrm{CaCl2}$. For confocal microscopy, $20 \mu \mathrm{l}$ of each sample were spread onto a glass slide and dried for 15 mins at RT. The slides were covered with PROlong Gold antifade reagent (Invitrogen, Darmstadt, Germany). Subsequently, confocal images were taken on a Zeiss LSM 5 Exciter confocal laser-scanning microscope.

\section{Intracellular $\mathrm{Ca}^{2+}$}

After incubation, erythrocytes were washed in Ringer solution and then loaded with Fluo-3/AM (Biotium, Hayward, USA) in Ringer solution containing $5 \mathrm{mM} \mathrm{CaCl}_{2}$ and $5 \mu \mathrm{M}$ Fluo-3/AM. The cells were incubated at $37^{\circ} \mathrm{C}$ for $30 \mathrm{~min}$ and washed once in Ringer solution containing $5 \mathrm{mM} \mathrm{CaCl}$. The Fluo-3/ AM-loaded erythrocytes were resuspended in $200 \mu \mathrm{l}$ Ringer solution. Then, $\mathrm{Ca}^{2+}$-dependent fluorescence intensity was measured in FL-1 with an excitation wavelength of $488 \mathrm{~nm}$ and an emission wavelength of $530 \mathrm{~nm}$ on a FACS Calibur. Afterwards, the geomean of the $\mathrm{Ca}^{2+}$ dependent fluorescence was determined.

Reactive oxygen species (ROS)

Oxidative stress was determined utilizing 2',7'-dichlorodihydrofluorescein diacetate (DCFDA). After incubation, a $150 \mu$ suspension of erythrocytes was washed in Ringer solution and then stained with DCFDA (Sigma Aldrich) in Ringer solution containing DCFDA at a final concentration of $10 \mu \mathrm{M}$. Erythrocytes were incubated at $37^{\circ} \mathrm{C}$ for $30 \mathrm{~min}$ in the dark and then washed two times in Ringer solution. The DCFDA-loaded erythrocytes were resuspended in $200 \mu \mathrm{l}$ Ringer solution, and ROS-dependent fluorescence intensity was measured in FL-1 at an excitation wavelength of $488 \mathrm{~nm}$ and an emission wavelength of $530 \mathrm{~nm}$ on a FACS Calibur (BD).

\section{Ceramide abundance}

To determine the ceramide abundance at the erythrocyte surface, a monoclonal antibody was used. After incubation, cells were stained for $1 \mathrm{~h}$ at $37^{\circ} \mathrm{C}$ with $1 \mu \mathrm{g} / \mathrm{ml}$ anti-ceramide antibody (clone MID 15B4; Alexis, Grünberg, Germany) in phosphate-buffered saline (PBS) containing $0.1 \%$ bovine serum albumin (BSA) at a dilution of 1:10. After two washing steps with PBS-BSA, cells were stained for 30 min with polyclonal fluorescein-isothiocyanate (FITC)-conjugated goat anti-mouse IgG/IgM (concentration $0.5 \mathrm{mg}$ / $\mathrm{ml}$ ) specific antibody (BD Pharmingen, Hamburg, Germany) diluted 1:50 in PBS-BSA. Unbound secondary antibody was removed by repeated washing with PBS-BSA. Samples were then analyzed by flow cytometric analysis in FL-1 at an excitation wavelength of $488 \mathrm{~nm}$ and an emission wavelength of $530 \mathrm{~nm}$. Finally, the geomean of the ceramide dependent fluorescence was determined.

\section{Statistics}

Data are expressed as arithmetic means \pm SEM. As indicated in the figure legends, statistical analysis was made using ANOVA with Tukey's test as post-test and $t$ test as appropriate. $\mathrm{n}$ denotes the number of different erythrocyte specimens studied. Since different erythrocyte specimens used in distinct experiments are differently susceptible to triggers of eryptosis, the same erythrocyte specimens have been used for control and experimental conditions.

\section{Results}

The present study explored whether Micafungin is able to trigger eryptosis, the suicidal erythrocyte death characterized by cell shrinkage and by phospholipid scrambling of the cell membrane with phosphatidylserine translocation to the cell surface. To this end, erythrocytes drawn from healthy volunteers were incubated for 48 hours in Ringer solution without or with Micafungin $(10-25 \mu \mathrm{g} / \mathrm{ml})$. 
A

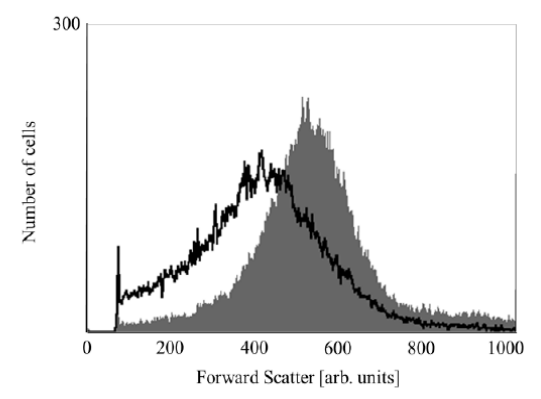

$\mathrm{C}$

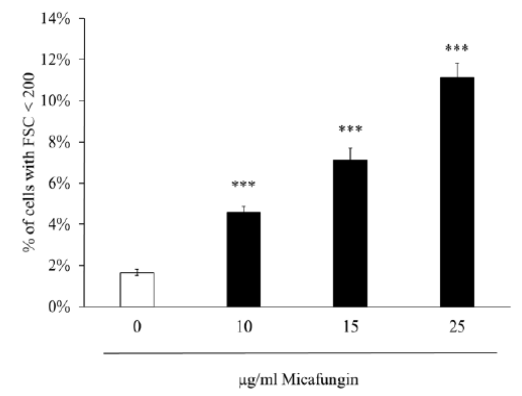

B

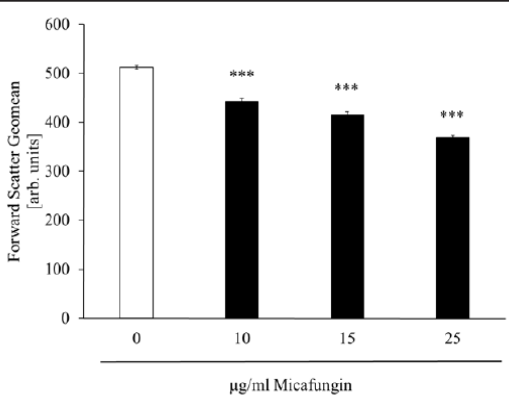

$\mathrm{D}$

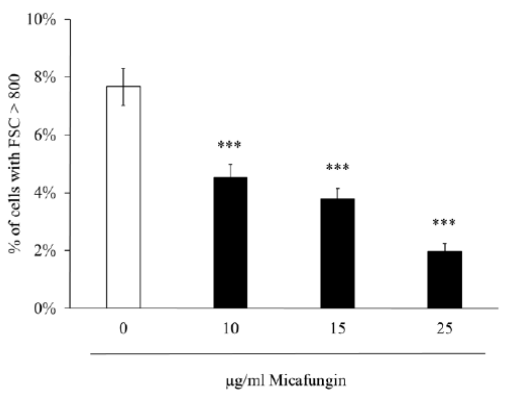

Fig. 1. Effect of Micafungin on erythrocyte forward scatter. A. Original histogram of forward scatter of erythrocytes following exposure for 48 hours to Ringer solution without (grey area) and with (black line) presence of $25 \mu \mathrm{g} / \mathrm{ml}$ Micafungin. B. Arithmetic means \pm SEM $(\mathrm{n}=14)$ of the erythrocyte forward scatter (FSC) following incubation for 48 hours to Ringer solution without (white bar) or with (black bars) Micafungin $(10-25 \mu \mathrm{g} / \mathrm{ml})$. C. Arithmetic means \pm SEM $(\mathrm{n}=14)$ of the percentage of erythrocytes with forward scatter (FSC) $<200$ following incubation for 48 hours to Ringer solution without (white bar) or with (black bars) Micafungin $(10-25 \mu \mathrm{g} / \mathrm{ml})$. D. Arithmetic means \pm SEM $(\mathrm{n}=14)$ of the percentage of erythrocytes with forward scatter (FSC) $>800$ following incubation for 48 hours to Ringer solution without (white bar) or with (black bars) Micafungin $(10-25 \mu \mathrm{g} / \mathrm{ml}) . * * *(p<0.001)$ indicates significant difference from the absence of Micafungin (ANOVA).

Erythrocyte volume was estimated from forward scatter, which was determined utilizing flow cytometry. As illustrated in Fig. 1, Micafungin $(10-25 \mu \mathrm{g} / \mathrm{ml})$ significantly decreased erythrocyte forward scatter. Moreover, Micafungin significantly increased the percentage of shrunken erythrocytes (Fig. 1C), an effect reaching statistical significance at $10 \mu \mathrm{g} / \mathrm{ml}$ Micafungin concentration. In contrast, Micafungin treatment decreased the percentage of swollen erythrocytes (Fig. 1D), an effect reaching statistical significance at 10 $\mu \mathrm{g} / \mathrm{ml}$ Micafungin concentration.

The percentage of hemolytic erythrocytes was estimated from hemoglobin concentration in the supernatant. As illustrated in Fig. 2, a 48 hours exposure to Micafungin (10 - $25 \mu \mathrm{g} /$ $\mathrm{ml}$ ) increased the percentage of hemolytic erythrocytes.

Phosphatidylserine exposing erythrocytes were identified utilizing annexin-V-binding, as determined by flow cytometry. As illustrated in Fig. 3, a 48 hours exposure to Micafungin $(10-25 \mu \mathrm{g} / \mathrm{ml})$ significantly increased the percentage of phosphatidylserine exposing erythrocytes.

Confocal microscopy was employed to visualize the annexin binding and the actin filaments of erythrocytes. As illustrated in Fig. 4, confocal microscopy confirmed the increase of annexin-V-binding. The actin filaments were apparently resistant to the Micafungin treatment (Fig. 4).

Fluo3 fluorescence was taken as a measure of cytosolic $\mathrm{Ca}^{2+}$ activity $\left(\left[\mathrm{Ca}^{2+}\right]_{\mathrm{i}}\right)$. As a result, the Fluo3 fluorescence was similar following incubation of the erythrocytes in the absence of Micafungin (21.16 \pm 0.56 a.u., $\mathrm{n}=14)$ and in the presence of $10 \mu \mathrm{g} / \mathrm{ml}(20.77 \pm 0.85$ a.u., $\mathrm{n}=$ 14), $15 \mu \mathrm{g} / \mathrm{ml}(19.78 \pm 0.72$ a.u., $\mathrm{n}=14)$ and $25 \mu \mathrm{g} / \mathrm{ml}(20.04 \pm 0.57$ a.u., $\mathrm{n}=14)$ Micafungin. Thus, Micafungin did not appreciably modify $\left[\mathrm{Ca}^{2+}\right]_{\mathrm{i}^{*}}$. 


\section{Cellular Physiology Cell Physiol Biochem 2016;39:584-595 \begin{tabular}{ll|l} 
DOI: 10.1159/000445650 & $\begin{array}{l}\text { O 2016 The Author(s). Published by S. Karger AG, Basel } \\
\text { www.karger.com/cpb }\end{array}$
\end{tabular}

Fig. 2. Effect of Micafungin on hemolysis. Arithmetic means \pm SEM $(n=8)$ of the percentage of hemolytic erythrocytes following incubation for 48 hours to Ringer solution without (white bar) or with (black bars) Micafungin $(10-25 \mu \mathrm{g} / \mathrm{ml}) \cdot{ }^{*}(\mathrm{p}<0.05)$, $* * *(\mathrm{p}<0.001)$ indicate significant difference from the absence of Micafungin (ANOVA).
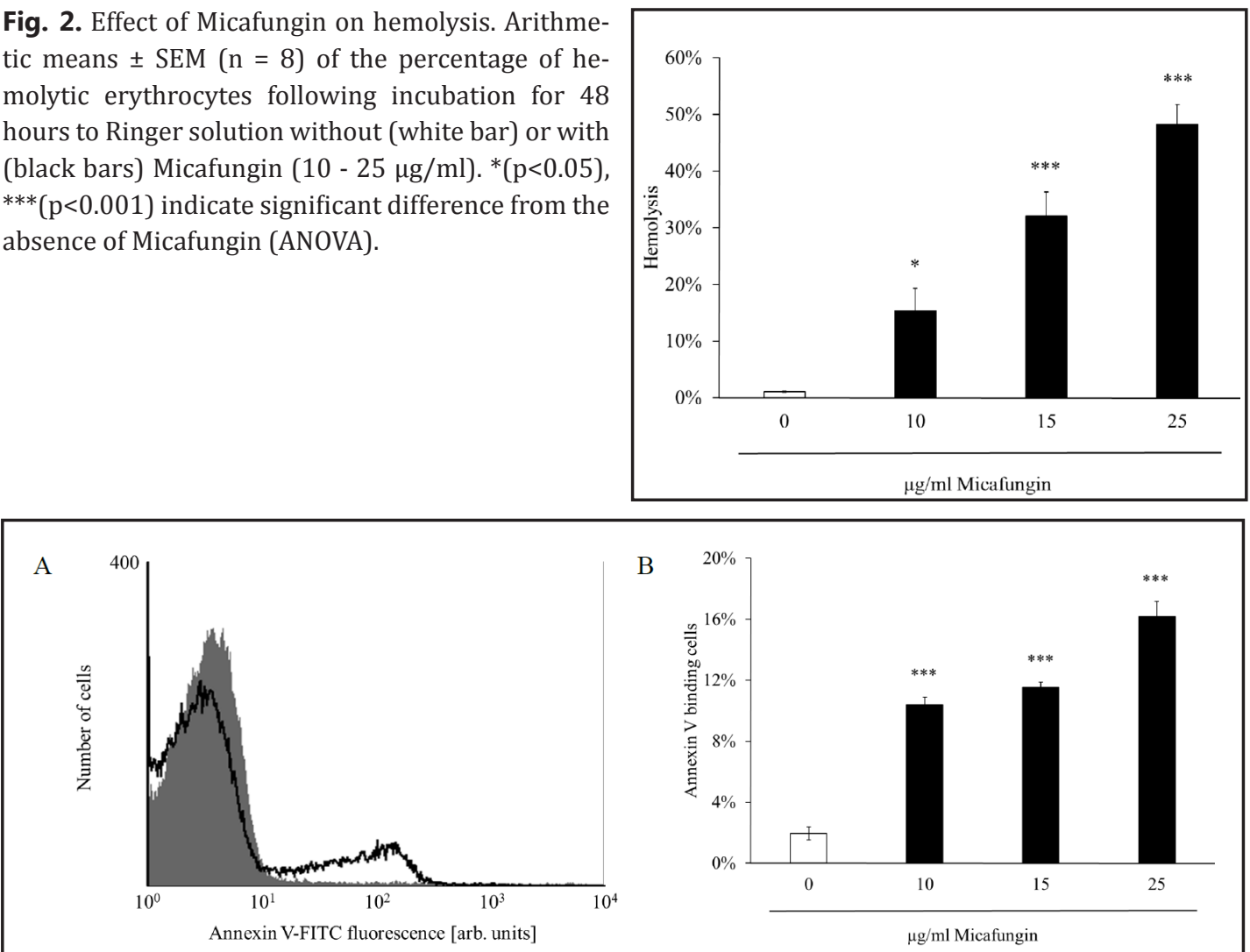

Fig. 3. Effect of Micafungin on phosphatidylserine exposure. A. Original histogram of annexin-V-binding of erythrocytes following exposure for 48 hours to Ringer solution without (grey area) and with (black line) presence of $25 \mu \mathrm{g} / \mathrm{ml}$ Micafungin. B. Arithmetic means \pm SEM $(\mathrm{n}=14)$ of erythrocyte annexin-V-binding following incubation for 48 hours to Ringer solution without (white bar) or with (black bars) Micafungin (10 - $25 \mu \mathrm{g} / \mathrm{ml}) .{ }^{* * *}(\mathrm{p}<0.001)$ indicates significant difference from the absence of Micafungin (ANOVA).

Fig. 4. Confocal microscopy on effects of Micafungin on phosphatidylserine externalization and F-actin. Confocal microscopy of annexin $\mathrm{V}$ fluorescence (left panels), F-actin abundance (middle panels) and overlay of both stainings (right panels) in erythrocytes following exposure to Ringer solution (upper panels) or to 10 $\mu \mathrm{g} / \mathrm{ml}$ micafungin for 48 hours (lower panels).
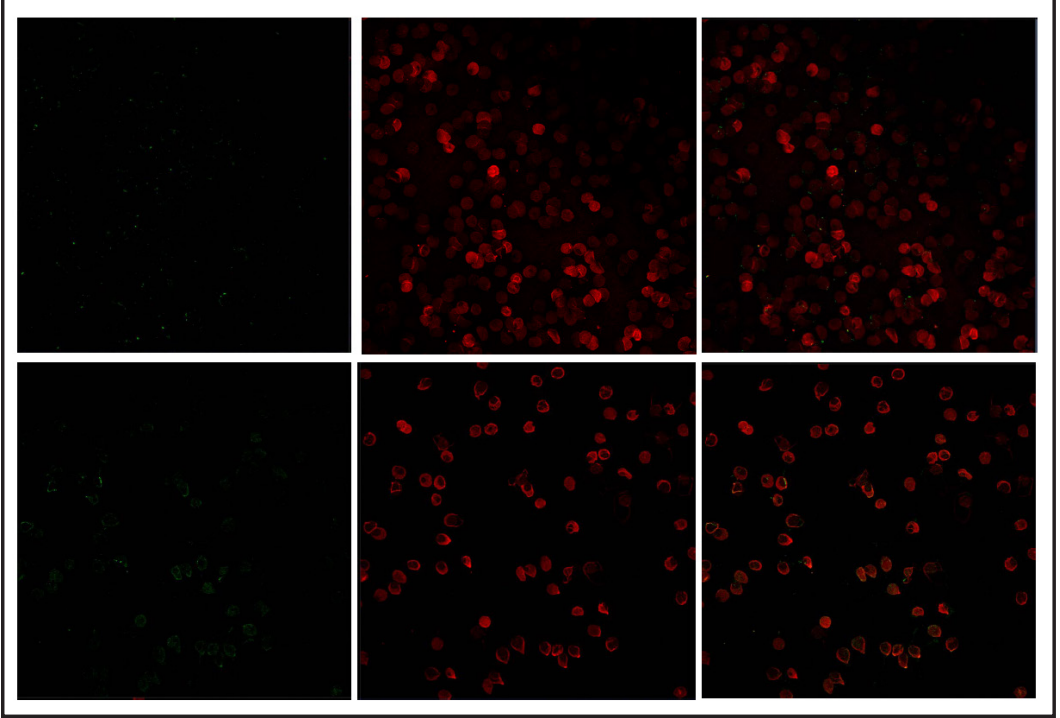

A next series of experiments explored whether the Micafungin-induced translocation of phosphatidylserine was sensitive to extracellular $\mathrm{Ca}^{2+}$. To this end, erythrocytes were incubated for 48 hours in the absence or presence of $25 \mu \mathrm{g} / \mathrm{ml}$ Micafungin in the presence 


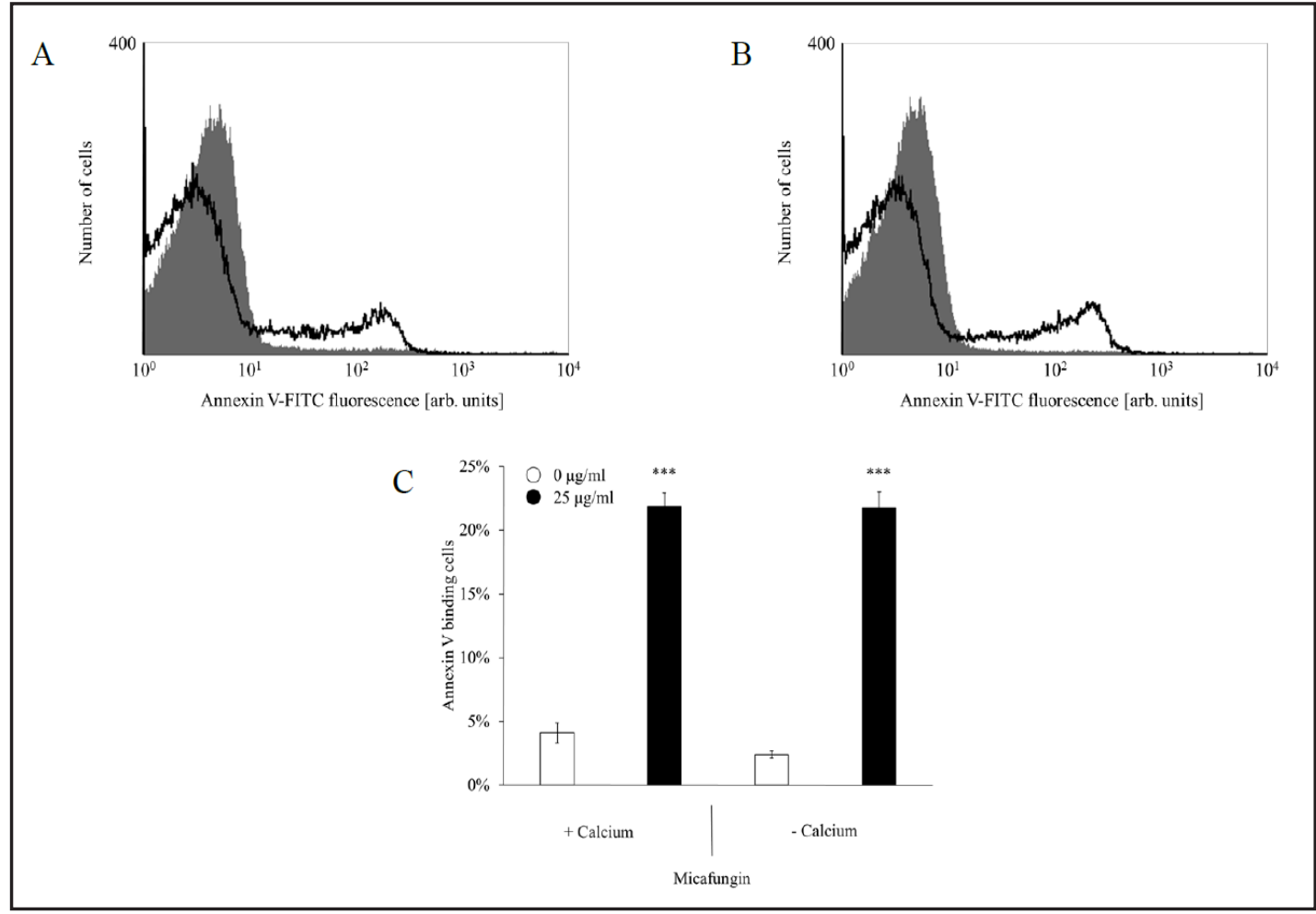

Fig. 5. $\mathrm{Ca}^{2+}$ insensitivity of Micafungin -induced phosphatidylserine exposure. A,B. Original histograms of annexin-V-binding of erythrocytes following exposure for 48 hours to Ringer solution without (grey area) and with (black line) Micafungin $(25 \mu \mathrm{g} / \mathrm{ml})$ in the presence (A) and absence (B) of extracellular $\mathrm{Ca}^{2+}$. C. Arithmetic means \pm SEM $(n=16)$ of annexin-V-binding of erythrocytes after a 48 hours treatment with Ringer solution without (white bars) or with (black bars) Micafungin $(25 \mu \mathrm{g} / \mathrm{ml}$ ) in the presence (left bars, + Calcium) and absence (right bars, - Calcium) of $\mathrm{Ca}^{2+}$. ${ }^{* *}(\mathrm{p}<0.001)$ indicates significant difference from the absence of Micafungin (ANOVA).

or nominal absence of extracellular $\mathrm{Ca}^{2+}$. As shown in Fig. 5, removal of extracellular $\mathrm{Ca}^{2+}$ did not significantly blunt the effect of Micafungin on the percentage of annexin-V-binding erythrocytes and even in the absence of extracellular $\mathrm{Ca}^{2+}$, Micafungin significantly increased the percentage of annexin-V-binding erythrocytes. Thus, Micafungin-induced cell membrane scrambling was not appreciably modified by removal of extracellular $\mathrm{Ca}^{2+}$.

Eryptosis is further stimulated by oxidative stress. Reactive oxygen species (ROS) was thus quantified utilizing $2^{\prime}, 7^{\prime}$-dichlorodihydrofluorescein diacetate (DCFDA). As shown in Fig. 6 A\&B, the DCFDA fluorescence was significantly $(p<0.001)$ lower in the presence of Micafungin than in the absence of Micafungin. Thus, Micafungin rather decreased oxidative stress.

To explore, whether the effects of Micafungin could be modified by the redox state, the influence of Micafungin on annexin-V-binding was tested in the absence or presence of antioxidant $\mathrm{N}$-acetylcysteine $(1 \mathrm{mM})$. As a result, Micafungin $(25 \mu \mathrm{g} / \mathrm{ml})$ increased the percentage of phosphatidylserine exposing erythrocytes to similar values in the absence (from $2.19 \pm 0.29 \%$ to $19.49 \pm 0.83 \%, \mathrm{n}=16$ ) and in the presence (from $1.58 \pm 0.16 \%$ to $17.16 \pm 0.88 \%, \mathrm{n}=16)$ of $\mathrm{N}$-acetylcysteine $(1 \mathrm{mM})$.

A further stimulator of eryptosis is ceramide. Ceramide abundance at the erythrocyte surface was thus quantified utilizing specific antibodies. As shown in Fig. 6 C\&D, the ceramide abundance was significantly lower following exposure to Micafungin, than in the absence of Micafungin. Thus, Micafungin rather decreased ceramide abundance.

In order to elucidate a possible role of $\mathrm{p} 38$ kinase, the influence of Micafungin on annexinV-binding was quantified in the absence or presence of p38 kinase inhibitor SB 203580 (2 KARGER 


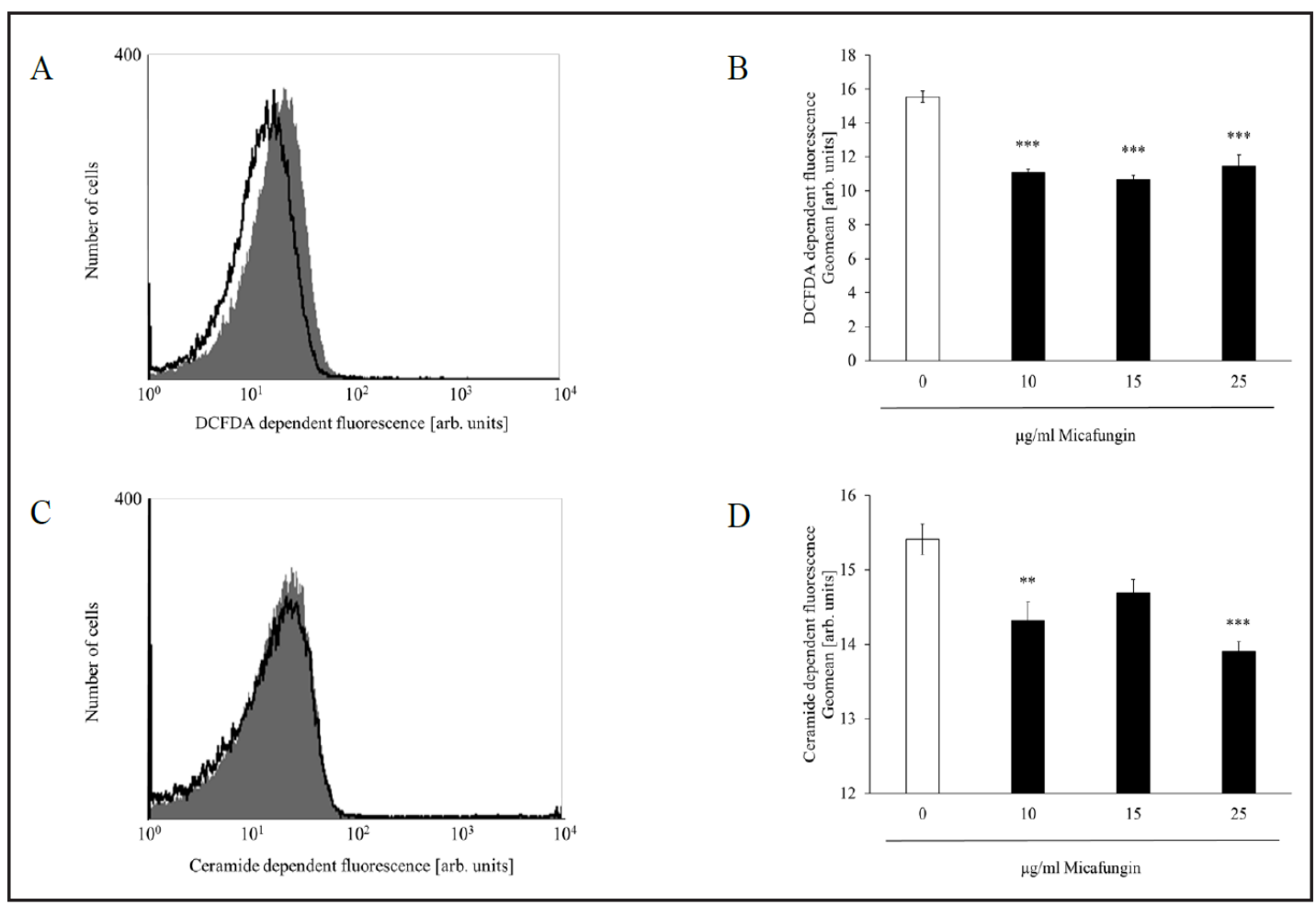

Fig. 6. Effect of Micafungin on ROS and ceramide abundance. A. Original histogram of DCFDA fluorescence of erythrocytes following exposure for 48 hours to Ringer solution without (grey area) and with (black line) presence of $25 \mu \mathrm{g} / \mathrm{ml}$ Micafungin. B. Arithmetic means \pm SEM ( $=5)$ of erythrocyte DCFDA fluorescence following incubation for 48 hours to Ringer solution without (white bar) or with (black bars) Micafungin (10 - $25 \mu \mathrm{g} / \mathrm{ml}$ ). C. Original histogram of ceramide abundance of erythrocytes following exposure for 48 hours to Ringer solution without (grey area) and with (black line) presence of $25 \mu \mathrm{g} / \mathrm{ml}$ Micafungin. D. Arithmetic means \pm SEM $(n=4)$ of erythrocyte ceramide abundance following incubation for 48 hours to Ringer solution without (white bar) or with (black bars) Micafungin $(10-25 \mu \mathrm{g} / \mathrm{ml}) .{ }^{* *}(\mathrm{p}<0.01),{ }^{* * *}(\mathrm{p}<0.001)$ indicate significant difference from the absence of Micafungin (ANOVA).

$\mu \mathrm{M})$. As a result, Micafungin $(25 \mu \mathrm{g} / \mathrm{ml})$ increased the percentage of phosphatidylserine exposing erythrocytes to similar values in the absence (from $2.93 \pm 0.70 \%$ to $17.79 \pm 0.85 \%$, $\mathrm{n}=8$ ) and in the presence (from $2.37 \pm 0.58 \%$ to $18.11 \pm 1.27 \%, \mathrm{n}=8)$ of SB $203580(2 \mu \mathrm{M})$.

The involvement of protein kinase $\mathrm{C}$ was tested by quantifying the effect of Micafungin on annexin-V-binding in the absence or presence of protein kinase $C$ inhibitor staurosporine $(1 \mu \mathrm{M})$. As a result, Micafungin $(25 \mu \mathrm{g} / \mathrm{ml})$ increased the percentage of phosphatidylserine exposing erythrocytes to similar values in the absence (from $3.29 \pm 0.58 \%$ to $20.03 \pm 0.96 \%$, $\mathrm{n}=16$ ) and in the presence (from $3.50 \pm 0.53 \%$ to $19.55 \pm 1.29 \%, \mathrm{n}=16$ ) of staurosporine $(1 \mu \mathrm{M})$.

A putative role of casein kinase $1 \alpha$ was studied by determination of Micafungin-induced annexin-V-binding in the absence or presence of casein kinase $1 \alpha$ inhibitor D4476 $(10 \mu \mathrm{M})$. As a result, Micafungin $(25 \mu \mathrm{g} / \mathrm{ml})$ increased the percentage of phosphatidylserine exposing erythrocytes to similar values in the absence (from $1.59 \pm 0.21 \%$ to $22.68 \pm 0.89 \%, \mathrm{n}=8$ ) and in the presence (from $1.54 \pm 0.11 \%$ to $21.83 \pm 1.04 \%, \mathrm{n}=8$ ) of $\mathrm{D} 4476(10 \mu \mathrm{M})$.

A final series of experiments addressed the putative involvement of caspases in Micafungin induced eryptosis. To this end, the influence of Micafungin on annexin-Vbinding was tested in the absence or presence of pancaspase inhibitor zVAD $(10 \mu \mathrm{M})$. As a result, Micafungin $(25 \mu \mathrm{g} / \mathrm{ml})$ increased the percentage of phosphatidylserine exposing erythrocytes to similar values in the absence (from $2.15 \pm 0.31 \%$ to $17.42 \pm 1.02 \%, \mathrm{n}=8$ ) and in the presence (from $2.12 \pm 0.26 \%$ to $19.61 \pm 1.30 \%, \mathrm{n}=8$ ) of zVAD $(10 \mu \mathrm{M})$.

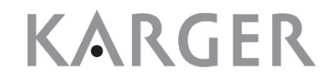




\section{Discussion}

The present observations demonstrate that Micafungin stimulates eryptosis, the suicidal erythrocyte death. Treatment of erythrocytes from healthy individuals with Micafungin results in cell shrinkage and cell membrane scrambling with phosphatidylserine translocation to the erythrocyte surface. The concentrations required for this effect are in the range of peak plasma concentrations determined in Micafungin treated patients [85]. At least in theory the sensitivity to Micafungin induced eryptosis could be enhanced in clinical conditions with accelerated eryptosis, such as dehydration [86], hyperphosphatemia [87], chronic kidney disease (CKD) [88-91], hemolytic-uremic syndrome [92], diabetes [93], hepatic failure [94], malignancy [42], sepsis [95], sickle-cell disease [42], beta-thalassemia [42], Hb-C and G6PD-deficiency [42], as well as Wilsons disease [96].

Attempts to define the signaling of Micafungin on erythrocyte cell membrane scrambling were not successful. According to the present observations, the involvement of several well known triggers of eryptosis, such as $\mathrm{Ca}^{2+}$ entry, oxidative stress, ceramide, protein kinase C, p38 kinase and caspases [42] is unlikely. Micafungin-induced cell membrane scrambling was not paralleled by increase of Fluo3 fluoresence and was not significantly modified by removal of $\mathrm{Ca}^{2+}$ from extracellular space, indicating that the effect was not dependent on entry of extracellular $\mathrm{Ca}^{2+}$. The effect of Micafungin on cell membrane scrambling was paralleled by a decrease rather than an increase of reactive oxygen species and was not significantly modified by the antioxidant $\mathrm{N}$-acetylcysteine. Micafungin further decreased rather than increased the abundance of ceramide. The effect of Micafungin on cell membrane scrambling was not sensitive to staurosporine, SB203580 or D4476 and did thus apparently not require the activation of protein kinase C, p38 kinase or casein kinase $1 \alpha$. Moreover, Micafungin was effective even in the presene of caspase inhibitor zVAD. Thus, the cellular mechanism involved in the triggering of eryptosis remained elusive.

Besides its effect on eryptosis, micafungin triggered hemolysis. The effects of Micafungin are reminiscent to the hemolytic effects of surfactant [97]. It is actually the purpose of eryptosis to clear defective erythrocytes from circulating blood prior to hemolysis [42]. The removal of defective erythrocytes is important as hemolysis leads to release of hemoglobin, which passes the renal glomerular filter, precipitates in the acidic lumen of renal tubules, occludes nephrons and may thus lead to renal failure [98]. Eryptosis further accomplishes removal of infected erythocytes from circulating blood [42].

\section{Conclusion}

In conclusion, Micafungin triggers eryptosis with cell shrinkage and cell membrane scrambling. In addition Micafungin and triggers hemolysis.

\section{Acknowledgements}

The authors acknowledge the meticulous preparation of the manuscript by Lejla Subasic and Tanja Loch. The study was supported by the Deutsche Forschungsgemeinschaft and Open Access Publishing Fund of Tuebingen University.

\section{Disclosure Statement}

The authors of this manuscript state that they have no conflicts of interest to declare.

\section{References}

1 Lehrnbecher T, Groll AH: Micafungin: a brief review of pharmacology, safety, and antifungal efficacy in pediatric patients. Pediatr Blood Cancer 2010;55:229-232.

\section{KARGER}




\section{Cellular Physiology Cell Physiol Biochem 2016;39:584-595 \begin{tabular}{l|l} 
and Biochemistry Published online: July 11,2016 & $\begin{array}{l}\text { D } 2016 \text { The Author(s). Published by S. Karger AG, Basel } \\
\text { www.karger.com/cpb }\end{array}$ \\
\hline
\end{tabular}}

Peter et al.: Micafungin-Induced Eryptosis

2 Shaaban H, Choo HF, Boghossian J, Perez G: Kodamaea ohmeri fungemia in an immunocompetent patient treated with micafungin: case report and review of the literature. Mycopathologia 2010;170:223-228.

3 Carver PL: Micafungin. Ann Pharmacother 2004;38:1707-1721.

4 Walia H, Tucci VT, Greene JN, Tordilla-Wadia J, Kelty P, Walia S: A case of endogenous trichosporon endophthalmitis treated with micafungin and voriconazole. J Glob Infect Dis 2009;1:71-74.

5 Ashouri N, Singh J, Arrieta A: Micafungin in pediatrics: when one size does not fit all. Expert Opin Drug Metab Toxicol 2008;4:463-469.

6 Ikeda F, Tanaka S, Ohki H, Matsumoto S, Maki K, Katashima M, Barrett D, Aoki Y: Role of micafungin in the antifungal armamentarium. Curr Med Chem 2007;14:1263-1275.

7 Chandrasekar PH, Sobel JD: Micafungin: a new echinocandin. Clin Infect Dis 2006;42:1171-1178.

8 Groll AH, Stergiopoulou T, Roilides E, Walsh TJ: Micafungin: pharmacology, experimental therapeutics and clinical applications. Expert Opin Investig Drugs 2005;14:489-509.

9 Matsumoto Y, Dogru M, Goto E, Fujishima H, Tsubota K: Successful topical application of a new antifungal agent, micafungin, in the treatment of refractory fungal corneal ulcers: report of three cases and literature review. Cornea 2005;24:748-753.

10 Zaas AK, Steinbach WJ: Micafungin: the US perspective. Expert Rev Anti Infect Ther 2005;3:183-190.

11 de la Torre P, Reboli AC: Micafungin: an evidence-based review of its place in therapy. Core Evid 2014;9:2739.

12 Emiroglu M: Micafungin use in children. Expert Rev Anti Infect Ther 2011;9:821-834.

13 Glockner A: Treatment and prophylaxis of invasive candidiasis with anidulafungin, caspofungin and micafungin:review of the literature. Eur J Med Res 2011;16:167-179.

14 Gumbo T: Single or 2-Dose Micafungin Regimen for Treatment of Invasive Candidiasis: Therapia Sterilisans Magna! Clin Infect Dis 2015;61 Suppl 6:S635-642.

15 Hinske LC, Weis F, Heyn J, Hinske P, Beiras-Fernandez A: The role of micafungin and anidulafungin in the treatment of systemic fungal infections: applications and patents for two novel echinocandins. Recent Pat Antiinfect Drug Discov 2012;7:1-7.

16 Manzoni P, Benjamin DK, Hope W, Rizzollo S, Del Sordo P, Stronati M, Jacqz-Aigrain E, Castagnola E, Farina D: The management of Candida infections in preterm neonates and the role of micafungin. J Matern Fetal Neonatal Med 2011;24:S24-27.

17 Manzoni P, Wu C, Tweddle L, Roilides E: Micafungin in premature and non-premature infants: a systematic review of 9 clinical trials. Pediatr Infect Dis J 2014;33:e291-298.

18 Scott LJ: Micafungin: a review of its use in the prophylaxis and treatment of invasive Candida infections. Drugs 2012;72:2141-2165.

19 Tascini C, Bongiorni MG, Tagliaferri E, Di Paolo A, Flammini S, Soldati E, Leonildi A, Di Cori A, Menichetti F: Micafungin for Candida albicans pacemaker-associated endocarditis: a case report and review of the literature. Mycopathologia 2013;175:129-134.

20 Wilke M: Treatment and prophylaxis of invasive candidiasis with anidulafungin, caspofungin and micafungin and its impact on use and costs: review of the literature. Eur J Med Res 2011;16:180-186.

21 Kofla G, Ruhnke M: Pharmacology and metabolism of anidulafungin, caspofungin and micafungin in the treatment of invasive candidosis: review of the literature. Eur J Med Res 2011;16:159-166.

22 Ascher S, Smith PB, Benjamin DK Jr: Safety of micafungin in infants: insights into optimal dosing. Expert Opin Drug Saf 2011;10:281-286.

23 Bormann AM, Morrison VA: Review of the pharmacology and clinical studies of micafungin. Drug Des Devel Ther 2009;3:295-302.

24 Temesgen Z, Barreto J, Vento S: Micafungin - the newest echinocandin. Drugs Today (Barc) 2009;45:469478.

25 Carter NJ, Keating GM: Micafungin: a review of its use in the prophylaxis and treatment of invasive Candida infections in pediatric patients. Paediatr Drugs 2009;11:271-291.

26 Natarajan G, Lulic-Botica M, Aranda JV: Refractory neonatal candidemia and high-dose micafungin pharmacotherapy. J Perinatol 2009;29:738-743.

27 Espinel-Ingroff A: In vitro antifungal activities of anidulafungin and micafungin, licensed agents and the investigational triazole posaconazole as determined by NCCLS methods for 12,052 fungal isolates: review of the literature. Rev Iberoam Micol 2003;20:121-136.

28 Fromtling RA: Micafungin sodium (FK-463). Drugs Today (Barc) 2002;38:245-257. 


\section{Cellular Physiology Cell Physiol Biochem 2016;39:584-595 \begin{tabular}{l|l} 
DOI: 10.1159/000445650 & $\begin{array}{l}\text { O 2016 The Author(s). Published by S. Karger AG, Basel } \\
\text { www.karger.com/cpb }\end{array}$
\end{tabular} \\ Peter et al.: Micafungin-Induced Eryptosis}

29 Higashiyama Y, Kohno S: Micafungin: a therapeutic review. Expert Rev Anti Infect Ther 2004;2:345-355.

30 Jarvis B, Figgitt DP, Scott LJ: Micafungin. Drugs 2004;64:969-982; discussion 983-964.

31 Cross SA, Scott LJ: Micafungin: a review of its use in adults for the treatment of invasive and oesophageal candidiasis, and as prophylaxis against Candida infections. Drugs 2008;68:2225-2255.

32 Scheinfeld N: A review of the new antifungals: posaconazole, micafungin, and anidulafungin. J Drugs Dermatol 2007;6:1249-1251.

33 Wiederhold NP, Cota JM, Frei CR: Micafungin in the treatment of invasive candidiasis and invasive aspergillosis. Infect Drug Resist 2008;1:63-77.

34 Vehreschild JJ, Cornely OA: Micafungin sodium, the second of the echinocandin class of antifungals: theory and practice. Future Microbiol 2006;1:161-170.

35 Fritz JM, Brielmaier BD, Dubberke ER: Micafungin for the prophylaxis and treatment of Candida infections. Expert Rev Anti Infect Ther 2008;6:153-162.

36 Wiederhold NP, Lewis JS, 2nd: The echinocandin micafungin: a review of the pharmacology, spectrum of activity, clinical efficacy and safety. Expert Opin Pharmacother 2007;8:1155-1166.

37 Joseph JM, Jain R, Danziger LH: Micafungin: a new echinocandin antifungal. Pharmacotherapy 2007;27:5367.

38 Cornely OA, Meems L, Herbrecht R, Viscoli C, van Amsterdam RG, Ruhnke M: Randomised, multicentre trial of micafungin vs. an institutional standard regimen for salvage treatment of invasive aspergillosis. Mycoses 2015;58:58-64.

39 Enoch DA, Idris SF, Aliyu SH, Micallef C, Sule 0, Karas JA: Micafungin for the treatment of invasive aspergillosis. J Infect 2014;68:507-526.

40 Nazzal M, Safi F, Arma F, Nazzal M, Muzaffar M, Assaly R: Micafungin-induced thrombotic thrombocytopenic purpura: a case report and review of the literature. Am J Ther 2011;18:e258-260.

41 Lang PA, Kaiser S, Myssina S, Wieder T, Lang F, Huber SM: Role of Ca2+-activated K+ channels in human erythrocyte apoptosis. Am J Physiol Cell Physiol 2003;285:C1553-C1560.

42 Lang E, Lang F: Mechanisms and pathophysiological significance of eryptosis, the suicidal erythrocyte death. Semin Cell Dev Biol 2015;39:35-42.

43 Borst O, Abed M, Alesutan I, Towhid ST, Qadri SM, Foller M, Gawaz M, Lang F: Dynamic adhesion of eryptotic erythrocytes to endothelial cells via CXCL16/SR-PSOX. Am J Physiol Cell Physiol 2012;302:C644-C651.

44 Andrews DA, Low PS: Role of red blood cells in thrombosis. Curr Opin Hematol 1999;6:76-82.

45 Chung SM, Bae ON, Lim KM, Noh JY, Lee MY, Jung YS, Chung JH: Lysophosphatidic acid induces thrombogenic activity through phosphatidylserine exposure and procoagulant microvesicle generation in human erythrocytes. Arterioscler Thromb Vasc Biol 2007;27:414-421.

46 Zwaal RF, Comfurius P, Bevers EM: Surface exposure of phosphatidylserine in pathological cells. Cell Mol Life Sci 2005;62:971-988.

47 Abed M, Towhid ST, Mia S, Pakladok T, Alesutan I, Borst O, Gawaz M, Gulbins E, Lang F: Sphingomyelinaseinduced adhesion of eryptotic erythrocytes to endothelial cells. Am J Physiol Cell Physiol 2012;303:C991999.

48 Closse C, Dachary-Prigent J, Boisseau MR: Phosphatidylserine-related adhesion of human erythrocytes to vascular endothelium. Br J Haematol 1999;107:300-302.

49 Gallagher PG, Chang SH, Rettig MP, Neely JE, Hillery CA, Smith BD, Low PS: Altered erythrocyte endothelial adherence and membrane phospholipid asymmetry in hereditary hydrocytosis. Blood 2003;101:46254627.

50 Pandolfi A, Di Pietro N, Sirolli V, Giardinelli A, Di Silvestre S, Amoroso L, Di Tomo P, Capani F, Consoli A, Bonomini M: Mechanisms of uremic erythrocyte-induced adhesion of human monocytes to cultured endothelial cells. J Cell Physiol 2007;213:699-709.

51 Wood BL, Gibson DF, Tait JF: Increased erythrocyte phosphatidylserine exposure in sickle cell disease: flowcytometric measurement and clinical associations. Blood 1996;88:1873-1880.

52 Lau IP, Chen H, Wang J, Ong HC, Leung KC, Ho HP, Kong SK: In vitro effect of CTAB- and PEG-coated gold nanorods on the induction of eryptosis/erythroptosis in human erythrocytes. Nanotoxicology 2012;6:847856. 


\section{Cellular Physiology Cell Physiol Biochem 2016;39:584-595 \begin{tabular}{l|l|l} 
and BOI: 10.1159/000445650 & $\begin{array}{l}\text { ( ) 2016 The Author(s). Published by S. Karger AG, Basel } \\
\text { www.karger.com/cpb }\end{array}$
\end{tabular} \\ Peter et al.: Micafungin-Induced Eryptosis}

53 Maellaro E, Leoncini S, Moretti D, Del Bello B, Tanganelli I, De Felice C, Ciccoli L: Erythrocyte caspase-3 activation and oxidative imbalance in erythrocytes and in plasma of type 2 diabetic patients. Acta Diabetol 2013;50:489-495.

54 Alzoubi K, Calabròa S, Bissinger R, Abed M, Faggio C, Lang F: Stimulation of Suicidal Erythrocyte Death by Artesunate. Cell Physiol Biochem 2014;34:2232-2244.

55 Alzoubi K, Egler J, Abed M, Lang F: Enhanced Eryptosis Following Auranofin Exposure. Cell Physiol Biochem 2015;37:1018-1028.

56 Arnold M, Bissinger R, Lang F: Mitoxantrone-induced suicidal erythrocyte death. Cell Physiol Biochem 2014;34:1756-1767.

57 Arnold M, Lang E, Modicano P, Bissinger R, Faggio C, Abed M, Lang F: Effect of nitazoxanide on erythrocytes. Basic Clin Pharmacol Toxicol 2014;114:421-426.

58 Bissinger R, Barking S, Alzoubi K, Liu G, Liu G, Lang F: Stimulation of Suicidal Erythrocyte Death by the Antimalarial Drug Mefloquine. Cell Physiol Biochem 2015;36:1395-1405.

59 Bissinger R, Bouguerra G, Stockinger K, Abbes S, Lang F: Triggering of Suicidal Erythrocyte Death by Topotecan. Cell Physiol Biochem 2015;37:1607-1618.

60 Bissinger R, Fischer S, Jilani K, Lang F: Stimulation of Erythrocyte Death by Phloretin. Cell Physiol Biochem 2014;34:2256-2265.

61 Bissinger R, Lupescu A, Zelenak C, Jilani K, Lang F: Stimulation of eryptosis by cryptotanshinone. Cell Physiol Biochem 2014;34:432-442.

62 Bouguerra G, Aljanadi O, Bissinger R, Abbes S, Lang F: Embelin-Induced Phosphatidylserine Translocation in the Erythrocyte Cell Membrane. Cell Physiol Biochem 2015;37:1629-1640.

63 Bouguerra G, Bissinger R, Abbes S, Lang F: Stimulation of Eryptosis by Narasin. Cell Physiol Biochem 2015;37:1807-1816.

64 Bouguerra G, Bissinger R, Abbes S, Lang F: Zopolrestat Induced Suicidal Death of Human Erythrocytes. Cell Physiol Biochem 2015;37:1537-1546.

65 Briglia M, Fazio A, Faggio C, Laufer S, Alzoubi K, Lang F: Triggering of Suicidal Erythrocyte Death by Ruxolitinib. Cell Physiol Biochem 2015;37:768-778.

66 Briglia M, Fazio A, Signoretto E, Faggio C, Lang F: Edelfosine Induced Suicidal Death of Human Erythrocytes. Cell Physiol Biochem 2015;37:2221-2230.

67 Calabro S, Alzoubi K, Faggio C, Laufer S, Lang F: Triggering of Suicidal Erythrocyte Death Following Boswellic Acid Exposure. Cell Physiol Biochem 2015;37:131-142.

68 Egler J, Lang F: Licochalcone A Induced Suicidal Death of Human Erythrocytes. Cell Physiol Biochem 2015;37:2060-2070.

69 Faggio C, Alzoubi K, Calabro S, Lang F: Stimulation of suicidal erythrocyte death by PRIMA-1. Cell Physiol Biochem 2015;35:529-540.

70 Fazio A, Briglia M, Faggio C, Alzoubi K, Lang F: Stimulation of Suicidal Erythrocyte Death by Garcinol. Cell Physiol Biochem 2015;37:805-815.

71 Jacobi J, Lang E, Bissinger R, Frauenfeld L, Modicano P, Faggio C, Abed M, Lang F: Stimulation of erythrocyte cell membrane scrambling by mitotane. Cell Physiol Biochem 2014;33:1516-1526.

72 Lang E, Jilani K, Bissinger R, Rexhepaj R, Zelenak C, Lupescu A, Lang F, Qadri SM: Vitamin D-Rich Diet in Mice Modulates Erythrocyte Survival. Kidney Blood Press Res 2015;40:403-412.

73 Lang E, Zelenak C, Eberhard M, Bissinger R, Rotte A, Ghashghaeinia M, Lupescu A, Lang F, Qadri SM: Impact of Cyclin-Dependent Kinase CDK4 Inhibition on Eryptosis. Cell Physiol Biochem 2015;37:1178-1186.

74 Lupescu A, Bissinger R, Goebel T, Salker MS, Alzoubi K, Liu G, Chirigiu L, Mack AF, Qadri SM, Lang F: Enhanced suicidal erythrocyte death contributing to anemia in the elderly. Cell Physiol Biochem 2015;36:773-783.

75 Lupescu A, Bissinger R, Herrmann T, Oswald G, Jilani K, Lang F: Induction of suicidal erythrocyte death by novobiocin. Cell Physiol Biochem 2014;33:670-680.

76 Lupescu A, Bissinger R, Warsi J, Jilani K, Lang F: Stimulation of erythrocyte cell membrane scrambling by gedunin. Cell Physiol Biochem 2014;33:1838-1848.

77 Malik A, Bissinger R, Calabro S, Faggio C, Jilani K, Lang F: Aristolochic Acid Induced Suicidal Erythrocyte Death. Kidney Blood Press Res 2014;39:408-419.

78 Officioso A, Alzoubi K, Manna C, Lang F: Clofazimine Induced Suicidal Death of Human Erythrocytes. Cell Physiol Biochem 2015;37:331-341. 


\section{Cellular Physiology Cell Physiol Biochem 2016;39:584-595 \begin{tabular}{l|l} 
and Biochemistry & $\begin{array}{l}\text { DOI: 10.1159/000445650 } \\
\text { Published online: Juty } 2016 \text { The Author(s). Published by S. Karger AG, Basel }\end{array}$ \\
\hline www.karger.com/cpb
\end{tabular} \\ Peter et al.: Micafungin-Induced Eryptosis}

79 Oswald G, Alzoubi K, Abed M, Lang F: Stimulation of suicidal erythrocyte death by ribavirin. Basic Clin Pharmacol Toxicol 2014;114:311-317.

80 Peter T, Bissinger R, Enkel S, Alzoubi K, Oswald G, Lang F: Programmed erythrocyte death following in vitro Treosulfan treatment. Cell Physiol Biochem 2015;35:1372-1380.

81 Stockinger K, Bissinger R, Bouguerra G, Abbes S, Lang F: Enhanced Eryptosis Following Exposure to Carnosic Acid. Cell Physiol Biochem 2015;37:1779-1791.

82 Tesoriere L, Attanzio A, Allegra M, Cilla A, Gentile C, Livrea MA: Oxysterol mixture in hypercholesterolemiarelevant proportion causes oxidative stress-dependent eryptosis. Cell Physiol Biochem 2014;34:10751089.

83 Waibel S, Bissinger R, Bouguerra G, Abbes S, Lang F: Saquinavir Induced Suicidal Death of Human Erythrocytes. Cell Physiol Biochem 2015;37:1973-1982.

84 Zierle J, Bissinger R, Egler J, Lang F: Lapatinib Induced Suicidal Death of Human Erythrocytes. Cell Physiol Biochem 2015;37:2275-2287.

85 Seibel NL, Schwartz C, Arrieta A, Flynn P, Shad A, Albano E, Keirns J, Lau WM, Facklam DP, Buell DN, Walsh TJ: Safety, tolerability, and pharmacokinetics of Micafungin (FK463) in febrile neutropenic pediatric patients. Antimicrob Agents Chemother 2005;49:3317-3324.

86 Abed M, Feger M, Alzoubi K, Pakladok T, Frauenfeld L, Geiger C, Towhid ST, Lang F: Sensitization of erythrocytes to suicidal erythrocyte death following water deprivation. Kidney Blood Press Res 2013;37:567-578.

87 Voelkl J, Alzoubi K, Mamar AK, Ahmed MS, Abed M, Lang F: Stimulation of suicidal erythrocyte death by increased extracellular phosphate concentrations. Kidney Blood Press Res 2013;38:42-51.

88 Abed M, Artunc F, Alzoubi K, Honisch S, Baumann D, Foller M, Lang F: Suicidal erythrocyte death in endstage renal disease. J Mol Med (Berl) 2014;92:871-879.

89 Ahmed MS, Langer H, Abed M, Voelkl J, Lang F: The uremic toxin acrolein promotes suicidal erythrocyte death. Kidney Blood Press Res 2013;37:158-167.

90 Polak-Jonkisz D, Purzyc L: Ca(2+) influx versus efflux during eryptosis in uremic erythrocytes. Blood Purif 2012;34:209-210; author reply 210.

91 Calderon-Salinas JV, Munoz-Reyes EG, Guerrero-Romero JF, Rodriguez-Moran M, Bracho-Riquelme RL, Carrera-Gracia MA, Quintanar-Escorza MA: Eryptosis and oxidative damage in type 2 diabetic mellitus patients with chronic kidney disease. Mol Cell Biochem 2011;357:171-179.

92 Lang PA, Beringer O, Nicolay JP, Amon O, Kempe DS, Hermle T, Attanasio P, Akel A, Schafer R, Friedrich B, Risler T, Baur M, Olbricht CJ, Zimmerhackl LB, Zipfel PF, Wieder T, Lang F: Suicidal death of erythrocytes in recurrent hemolytic uremic syndrome. J Mol Med (Berl) 2006;84:378-388.

93 Nicolay JP, Schneider J, Niemoeller OM, Artunc F, Portero-Otin M, Haik G, Jr., Thornalley PJ, Schleicher E, Wieder T, Lang F: Stimulation of suicidal erythrocyte death by methylglyoxal. Cell Physiol Biochem 2006;18:223-232.

94 Lang E, Gatidis S, Freise NF, Bock H, Kubitz R, Lauermann C, Orth HM, Klindt C, Schuier M, Keitel V, Reich M, Liu G, Schmidt S, Xu HC, Qadri SM, Herebian D, Pandyra AA, Mayatepek E, Gulbins E, Lang F, Haussinger D, Lang KS, Foller M, Lang PA: Conjugated bilirubin triggers anemia by inducing erythrocyte death. Hepatology 2015;61:275-284.

95 Kempe DS, Akel A, Lang PA, Hermle T, Biswas R, Muresanu J, Friedrich B, Dreischer P, Wolz C, Schumacher U, Peschel A, Gotz F, Doring G, Wieder T, Gulbins E, Lang F: Suicidal erythrocyte death in sepsis. J Mol Med (Berl) 2007;85:273-281.

96 Lang PA, Schenck M, Nicolay JP, Becker JU, Kempe DS, Lupescu A, Koka S, Eisele K, Klarl BA, Rubben H, Schmid KW, Mann K, Hildenbrand S, Hefter H, Huber SM, Wieder T, Erhardt A, Haussinger D, Gulbins E, Lang F: Liver cell death and anemia in Wilson disease involve acid sphingomyelinase and ceramide. Nat Med 2007;13:164-170.

97 Manaargadoo-Catin M, Ali-Cherif A, Pougnas JL, Perrin C: Hemolysis by surfactants--A review. Adv Colloid Interface Sci 2016;228:1-16.

98 Harrison HE, Bunting H, Ordway NK, Albrink WS: The Pathogenesis of the Renal Injury Produced in the Dog by Hemoglobin or Methemoglobin. J Exp Med 1947;86:339-356. 